\title{
Pengaruh Skeptisme Profesional, Kompetensi, dan Independensi Pada Kualitas Audit
}

\author{
Putu Dendy Pratama Yoga ${ }^{1}$ \\ Ni Luh Sari Widhiyani ${ }^{2}$ \\ ${ }^{1,2}$ Fakultas Ekonomi dan Bisnis Universitas Udayana (Unud), Bali, Indonesia \\ e-mail: dendypratamaa@yahoo.com
}

\begin{abstract}
ABSTRAK
Penelitian ini bertujuan untuk menguji serta memberikan bukti empiris bagaimana pengaruh skeptisme profesional, kompetensi, dan independensi pada kualitas audit di Kantor BPK Bali. Penelitian ini mengambil sampel yaitu seluruh auditor yang bekerja di Kantor BPK Bali minimal 1 tahun berdasarkan metode non probability sampling dengan teknik purposive sampling dan sampel berjumlah 40 auditor. Pengumpulan data dilakukan dengan metode survei dengan teknik kuesioner. Teknik analisis dalam penelitian ini menggunakan analisis regresi linier berganda. Hasil analisis menunjukkan bahwa skeptisme professional, kompetensi dan independensi berpengaruh positif pada kualitas audit. Hal ini menunjukan bahwa semakin tinggi skeptisme profesional, kompetensi, dan independensi yang dimiliki oleh auditor maka kualitas audit yang dihasilkan semakin baik.
\end{abstract}

Kata kunci: Skeptisme profesional, kompetensi, independensi dan kualitas audit.

\begin{abstract}
This study aims to examine and provide empirical evidence on how the influence of professional skepticism, competence, and independence on audit quality at the BPK Office at least a year experienced in Bali. This study took a sample of all auditors at the BPK Bali Office based on non probability sampling methods with purposive sampling technique and a sample of 40 auditors. Data collection is done by survey method with questionnaire techniques. The analysis technique in this study used multiple linear regression analysis. The results of the analysis show that professional skepticism, competence and independence have a positive effect on audit quality. This shows that the higher the professional skepticism, competence, and independence possessed by the auditor, the better the quality of the audit produced.

Keywords: Professional skepticism, competence, independence and audit quality.
\end{abstract}

\section{PENDAHULUAN}

Badan Pemeriksa Keuangan (BPK) adalah Sebuah lembaga Negara yang diberikan tugas untuk memeriksa pengelolaan serta bertanggung jawab pada kondisi keuangan Negara yang dimaksud dalam Undang - Undang Dasar Republik Indonesia Tahun 1945. Badan Pemeriksa Keuangan atau singkatan dari 
Putu Dendy Pratama Yoga dan Ni Luh Sari Widhiyani. Pengaruh ...

BPK untuk melaksanakan tugasnya selalu berpedoman pada Standar Pemeriksaan Keuangan Negara (SPKN). Di dalam SPKN tercantum persyaratan tentang profesionalisme pemeriksa, mutu pemeriksaan serta persyaratan laporan pemeriksaan yang profesional dalam bidang tersebut. (SPKN, 2007). Auditor Badan Pemeriksa Keuangan (BPK RI) Perwakilan Provinsi Bali mendapat tuntutan dari masyarakat sekitar untuk meningkatkan kualitas audit yang ada guna dapat mengurusi maraknya kasus korupsi serta penindaklanjutannya (Febriani, 2016).

Satu kasus yang menyita perhatian kita terhadap kualitas audit Badan Pemeriksa Keuangan di Indonesia adalah operasi tangkap tangan yang dilakukan oleh Auditor Utama BPK dan Irjen Kementrian Desa yang terjadi pada Jumat, 26 Mei 2017. Komisi Pemberantasan Korupsi (KPK) menahan Auditor Madya pada Sub Auditorat VII B2 Badan Pemeriksa Keuangan (BPK) Sigit Yugoharto. Sigit ditetapkan sebagai tersangka pada kasus suap terkait temuan pemeriksaan dengan tujuan tertentu (PDTT) oleh BPK tahun 2017, terhadap kantor cabang PT Jasa Marga (Persero) Purbaleunyi. Juru Bicara KPK Febri Diansyah mengatakan, Sigit sudah ditahan sejak Rabu (20/9/2017), setelah KPK memeriksa yang bersangkutan. "Pada Rabu setelah melakukan pemeriksaan terhadap SGY, dilakukan pehananan untuk SGY," kata Febri, dalam jumpa pers di gedung KPK (Kompas, 2017). Kasus ini membuat masyarakat menjadi tidak percaya lagi terhadap kualitas audit Lembaga pemerintahan. Untuk meningkatkan kembali 
kepercayaan masyarakat, BPK harus lebih memperhatikan kinerja auditor dalam menjalankan tugasnya.

Auditor merupakan seorang akuntan publik yang sudah bersertifikasi untuk melaksanakan pekerjaan berlandaskan kemampuan yang dimiliki. Dalam standar audit, seorang auditor diharuskan memiliki kemampuan, keahlian, dan pelatihan teknis yang cukup dalam melakukan audit serta memiliki kode etik profesional dalam menjalankan tugas sebagai auditor. Seorang auditor bertugas untuk melakukan audit dengan tujuan mencari keterangan tentang apa yang dilaksanakan dalam suatu entitas yang diperiksa, membandingkan hasil dengan kriteria yang ditetapkan, serta menyetujui atau menolak hasil dengan memberikan rekomendasi tentang tindakan-tindakan perbaikan (Sari \& Ramantha, 2015).

Seorang auditor harus memperhatikan kualitas auditnya, karena dengan kualitas audit yang tinggi diharapkan dapat menghasilkan laporan keuangan yang dapat dipercaya oleh pengguna informasi keuangan. Berdasarkan Standar Profesional Akuntan Publik (SPAP) audit yang dilaksanakan auditor tersebut dapat berkualitas jika memenuhi ketentuan atau standar auditing. Badjuri (2011) menyatakan kualitas audit dikatakan sebagai keadaan dimana seorang auditor akan menemukan dan melaporkan ketidaksesuaian terhadap prinsip yang terjadi pada laporan akuntansi kliennya. Salah satu pendekatan yang digunakan adalah pendekatan yang berorientasi hasil dan pendekatan yang berorientasi proses (Jones \& Bowrey, 2013). 
Putu Dendy Pratama Yoga dan Ni Luh Sari Widhiyani. Pengaruh ...

Pemberian pendapat mengenai laporan keuangan yang telah diaudit, seorang auditor harus mengevaluasi secara kritis bukti audit, menggunakan kompetensi yang dimilikinya secara objektif dan independen. Maka tingginya kualitas audit menentukan sebagaimana kualitas auditor itu sendiri dalam melaksanakan tugas yang diberikan. Semakin tinggi kualitas audit maka semakin tinggi pula tingkat kepercayaan pada laporan keuangan yang telah diaudit.

Menurut DeAngelo (1981)kualitas audit dikatakan sebagai keadaan dimana seorang auditor akan menemukan dan melaporkan ketidaksesuaian terhadap prinsip yang terjadi pada laporan akuntansi kliennya. Baik buruknya kualitas audit dipengaruhi oleh dilematis yang dialami auditor, hal ini dikarenakan klien mempunyai kepentingan yang berbeda, bahkan mungkin bertentangan dengan kepentingan para pemakai laporan keuangan. Seharusnya auditor tidak hanya berfokus pada kepentingan klien, tetapi juga fokus terhadap kualitas audit yang akan diberikan kepada pihak-pihak yang berkepentingan terhadap laporan keuangan tersebut. Hal ini dikarenakan Kualitas audit dapat membangun kredibilitas informasi dan kualitas informasi pelaporan keuangan yang juga membantu pengguna memiliki informasi yang berguna (Chanawongse, 2011).

Penting bagi auditor untuk menjaga kualitas audit supaya tidak menyesatkan para pemakainya dalam mengambil keputusan. Kualitas audit adalah terjaminya kredibilitas dan keandalan informasi yang tersaji dalam laporan audit karena kepatuhan auditor pada standar audit yang berlaku selama penugasan audit. 
Unsur-unsur kualitas laporan audit yaitu tepat waktu, lengkap, akurat, obyektif, meyakinkan, jelas dan ringkas (BPK-RI, 2007).

Sebuah kualitas audit yang baik dapat dipengaruhi dari skeptisme professional. Skeptisme profesional merupakan sikap dimana seorang auditor selalu mempertanyakan serta melakukan evaluasi bukti audit dengan kritis (Standar Profesional Akuntan Publik IAPI, 2011). Indah (2010) menyatakan apabila seorang auditor memiliki sikap skeptisme profesional yang tinggi maka kualitas audit yang dihasilkan akan semakin baik. Dalam Internasional Standar Auditing (IAASB, 2009) juga ditekankan pentingnya skeptisme profesional. Disebutkan bahwa auditor harus merencanakan dan melaksanakan proses berlandaskan skeptisme profesional dengan menyadari kemungkinan terjadinya keslahan material dalam laporan keuangan. Pekerjaan auditor selalu berhubungan dengan pembuktian dan pencarian kebenaran bukti-bukti dari dokumen dan kertas kerja, dan dari prosedur standar yang mereka anut, namun hal ini bukan berarti auditor hanya bekerja untuk memenuhi prosedur standar yang ada, terutama saat ditemukannya buktibukti yang penting. Selain dilihat dari skeptisme professional, kualitas audit juga dapat dipengaruhi oleh kompetensi dan independensi.

Menurut Christiawan (2002) dalam Nugraha (2012), bahwa kualitas audit ditentukan oleh dua hal yaitu kompetensi dan independensi. American Accounting Association (AAA) Financial Accounting Commite (2000) menyatakan kompetensi merupakan salah satu yang bisa membuktikan kualitas audit, sehingga kualitas audit dipengaruhi langsung oleh kompetensi. Saifuddin (2004) 
Putu Dendy Pratama Yoga dan Ni Luh Sari Widhiyani. Pengaruh ...

keterampilan mengerjakan pekerjaan dengan cepat, mudah, intuitif, tidak pernah melakukan kesalahan merupakan cerminan dari orang yang berkompeten. Karnisa (2015) menunjukkan bahwa kompetensi berpengaruh positif. Penelitian ini sejalan dengan Marganingsih (2016) menunjukkan bahwa kompetensi berpengaruh terhadap kualitas audit. Tetapi hasil penelitian yang dilakukan oleh Oklivia \& Marlinah (2014) menunjukkan bahwa kompetensi tidak berpengaruh terhadap kualitas audit. Sejalan dengan hasil penelitian Andarwanto (2015) menunjukkan bahwa kompetensi tidak berpengaruh terhadap kualitas audit.

Namun sesuai dengan tanggungjawabnya untuk menaikkan tingkat keandalan laporan keuangan suatu perusahaan maka akuntan publik tidak hanya perlu memiliki sikap skeptisme profesional dan kompetensi atau keahlian saja tetapi juga harus independen dalam pengauditannya. Seorang akuntan publik harus independen dalam melakukan pengauditan. Auditor harus melaksanakan kewajiban untuk bersikap jujur tidak hanya kepada manajemen dan pemilik perusahaan, namun juga kepada kreditor dan pihak lain yang meletakkan kepercayaan atas laporan keuangan auditan. Berkualitas atau tidaknya pekerjaan auditor akan mempengaruhi kesimpulan akhir auditor dan secara tidak langsung juga akan mempengaruhi tepat atau tidaknya keputusan yang akan diambil oleh pihak luar perusahaan. Standar umum kedua (SA seksi 220 dalam SPAP, 2009) menyebutkan bahwa dalam semua hal yang berhubungan dengan perikatan, independensi dalam sikap mental harus dipertahankan oleh auditor. Standar ini mengharuskan bahwa auditor harus bersikap independen (tidak mudah 
dipengaruhi), karena ia melaksanakan pekerjaannya untuk kepentingan umum. Auditor harus melaksanakan kewajiban untuk bersikap jujur tidak hanya kepada manajemen dan pemilik perusahaan, namun juga kepada kreditor dan pihak lain yang meletakkan kepercayaan atas laporan keuangan auditan (Elfarini, 2007). Castellani (2008) menemukan hasil bahwa independensi berpengaruh pada kualitas audit. Ardini (2010) mendukung bahwa variabel independensi berpengaruh terhadap kualitas audit. Tetapi hasil berbeda diungkapkan oleh Rapina et al. (2010), Sari \& Ramantha (2015) yang menunjukkan bahwa independensi auditor tidak berpengaruh pada kualitas audit. Febriyanti (2014) dan Amanda (2014) yang menyatakan bahwa Independensi dan Akuntanbilitas tidak berpengaruh signifikan terhadap kualitas audit.

Kualitas audit tidak dapat dipisahkan dari teori keagenan (agency theory). Teori keagenan merupakan bagian dari akuntansi keperilakuan (behavioral accounting) yang merupakan cabang akuntansi yang mempelajari hubungan antara perilaku manusia dengan sistem akuntansi. Kualitas audit menurut De angelo dalam Ayu (2013) merupakan sebagai probabilitas seorang auditor dapat menemukan dan melaporkan penyelewengan dalam sistem akuntansi klien. Faisal (2012), kualitas audit merupakan probabilitas seseorang auditor atau akuntan pemeriksa menemukan penyelewengan dalam sistem akuntansi suatu unit atau lembaga, kemudian melaporkannya dalam laporan audit.

Menurut DeAngelo (1981) bahwa kualitas audit terdiri dari dua komponen hal tersebut juga digunakan oleh AAA Financial Accounting Standard Committee, 
Putu Dendy Pratama Yoga dan Ni Luh Sari Widhiyani. Pengaruh ...

2011 yaitu : mendefinisikan kualitas audit sebagai kemungkinan (probability) auditor yang akan menemukan pelanggaran tergantung pada kompetensi auditor dan melaporkan pelanggaran yang ada dalam sistem akuntansi klien tergantung pada independensi auditor, oleh karena itu kualitas audit yang baik harus dibangun sejak awal pelaksanaan audit hingga pelaporan dan pemberian rekomendasi. Ini bertujuan agar pihak auditor bisa mengontrol saat pertama kali pelaksanaan audit, kemudian memberikan hasil yang memadai terhadap laporan keuangan yang akan di audit.

Penurunan Kualitas audit dimasa singkat dikarenakan kurangnya kompetensi, hilangnya independensi, dan objektivitas auditor. Sementara kehilangan kualitas dalam audit masa yang panjang kemungkinan besar karena hilangnya independensi. Hay dan Knechel (2010) serta dikuti oleh Adeniyi (2013), audit bisa dikategorikan sebagai jenis kepercayaan yang baik dikarenakan pendapat tentang representasi yang benar dan adil, tetapi hanya sejauh pengguna laporan keuangan menganggap bahwa pendapat itu berharga. Untuk menghasilkan kualitas audit yang baik, auditor menjalankan profesinya harus berpedoman pada kode etik akuntan, standar profesi, dan standar akuntansi keuangan yang berlaku di Indonesia (Mawar, 2010)

Maka dapat disimpulkan bahwa kualitas audit merupakan penelitian yang dilakukan oleh auditor dengan maksud menemukan kejadian-kejadian serta melaporkan penyimpangan dan ketidaksesuaian dengan standar yang berlaku. 
Skeptisme berasal dari kata skeptic, dalam kamus besar bahasa Indonesia (Pusat Bahasa, 2008) berarti sikap meragukan, mencurigai, dan tidak mempercayai kebenaran suatu hal, teori, ataupun pernyataan. Skeptisme profesional auditor adalah suatu sikap dalam melakukan penugasan audit. Dalam buku istilah akuntansi dan auditing, skeptisme berarti bersikap ragu-ragu terhadap pernyataan-pernyataan yang belum cukup kuat dasar-dasar pembuktiannya (Islahuzzaman, 2012), sedangkan profesional, menurut Kamus Besar Bahasa Indonesia (Pusat Bahasa, 2008) adalah sesuatu yang bersangkutan dengan profesi, yang membutuhkan keahlian khusus untuk menerapkannya. Kata profesional dalam skeptisme profesional merujuk pada fakta bahwa auditor telah dan terus dididik dan dilatih untuk menerapkan keahliannya dalam mengambil keputusan sesuai standar keahliannya dalam mengambil keputusan sesuai standar profesionalnya. Namun dari definisi kata skeptisme dan profesional tersebut, dapat disimpulkan bahwa skeptisme profesional auditor adalah sikap auditor yang selalu meragukan dan mempertanyakan segala sesuatu, dan menilai secara kritis bukti audit serta mengambil keputusan audit berlandaskan keahlian auditing yang dimiliknya. Skeptisme bukan berarti tidak percaya, tapi mencari pembuktian sebelum dapat mempercayai suatu pernyataan (CAQ, 2010).

Standar Profesi Akuntan Publik (SPAP, 2012) menyatakan skeptisme profesional auditor sebagai suatu sikap yang mencakup pikiran yang selalu mempertanyakan dan melakukan evaluasi secara kritis terhadap bukti audit. Skeptisme profesional digabungkan ke dalam literature profesional yang 
Putu Dendy Pratama Yoga dan Ni Luh Sari Widhiyani. Pengaruh ...

membutuhkan auditor untuk mengevaluasi kemungkinan kecurangan material. Selain itu juga dapat di artikan sebagai pilihan untuk memenuhi tugas audit profesionalnya untuk mencegah dan mengurangi konsekuensi bahaya dan perilaku orang lain. Skeptisme profesional auditor dapat dipengaruhi oleh beberapa faktor. Faktor-faktor tersebut antara lain kompetensi dan independensi.

Skeptisme Professional adalah sebuah sikap yang harus dimiliki oleh auditor profesional. Sikap yang mencangkup pikiran selalu mempertanyakan dan melakukan evaluasi secara kritis terhadap bukti audit. Sikap skeptis auditor mengharuskan seorang auditor untuk mengevaluasi kemungkinan terjadinya kecurangan atau penyalahgunaan wewenang yang material yang terjadi di dalam orgnisasi, Hurrt (2007) dalam Dwiyani (2010) mendefinisikan skeptisme sebagai kecenderungan individu untuk menunda memberikan kesimpulan hingga bukti audit cukup untuk memberikan dukungan maupun penjelasan. Semakin skeptis seorang auditor maka semakin mengurangi tingkat kesalahan dalam melakukan audit Bell et al. (2005). Auditor yang kurang memiliki sikap skeptisme profesional akan menyebabkan penurunan kualitas audit.

Penelitian yang dilakukan oleh Januarti dan Faial (2010) menunjukkan hasil bahwa skeptisme profesional auditor mempunyai pengaruh yang positif terhadap kualitas hasil audit Prima \& Rohman (2012), menunjukkan hasil bahwa skeptisme profesional auditor berpengaruh positif terhadap kualitas audit, sehingga semakin skeptis seorang auditor semakin baik kualitas audit yang dilakukannya. Penelitian yang dilakukan oleh Sari \& Ramantha (2015) 
menunjukkan hasil bahwa skeptisme profesional auditor berpengaruh positif dan signifikan terhadap kualitas audit. Skeptisme profesional sangat diperlukan untuk meningkatkan kualitas audit, karena dengan bersikap skeptis, auditor akan lebih berinisiatif mencari informasi lebih lanjut dari manajemen mengenai keputusankeputusan akuntansi yang diambil.

Berdasarkan hasil penelitian di atas serta kesimpulan dari landasan teori yang ada, maka dapat ditetapkan hipotesis sebagai berikut :

$\mathrm{H}_{1}$ : Skeptisme professional berpengaruh positif pada kualitas audit.

Kompetensi auditor adalah auditor yang dengan pengetahuan dan pengalamannya yang cukup dan eksplisit dapat melakukan audit secara objektif, cermat dan seksama. Auditor yang berkompeten adalah auditor yang dengan pengetahuan dan pengalamanya yang cukup dan eksplisit dapat melakukan audit secara objektif, cermat dan seksama (Elfarini, 2007). Audit menuntut keahlian dan profesionalisme yang tinggi. Keahlian tersebut tidak hanya dipengaruhi oleh pendidikan formal tapi juga dipengaruhi oleh pengalaman. Menurut Tubbs (1992) auditor yang berpengalaman memiliki keunggulan dalam hal 1) mendeteksi kesalahan, 2) memahami kesalahan secara akurat dan 3) mencari penyebab kesalahan. Oleh karena itu dapat dipahami bahwa seorang auditor yang berkompeten memiliki pengetahuan audit dan pengalaman yang memadai, akan lebih memahami dan mengetahui berbagai masalah secara lebih mendalam dan lebih mudah dalam mengikuti perkembangan yang semakin kompleks dalam lingkungan auditnya. 
Putu Dendy Pratama Yoga dan Ni Luh Sari Widhiyani. Pengaruh ...

Penelitian Christiawan (2002) dan Alim et al. (2007) dalam Sukriah et al. (2009) menyatakan bahwa semakin tinggi kompetensi auditor akan semakin baik kualitas hasil pemeriksaannya. Kemudian Ermayanti (2009) mengemukakan setiap auditor harus melaksanakan jasa profesionalnya dengan hati-hati, kompetensi dan ketekunan, serta mempunyai kewajiban untuk mempertahankan pengetahuan dan keterampilan professional. Penelitian Anugerah \& Akbar (2014) menyatakan bahwa kompetensi berpengaruh positif terhadap kualitas audit. Penelitian yang dilakukan Anugerah \& Akbar (2014) menunjukkan bahwa kompetensi berpengaruh positif terhadap kualitas audit.

Berdasarkan hasil penelitian di atas serta kesimpulan dari landasan teori yang ada, maka dapat ditetapkan hipotesis sebagai berikut :

$\mathrm{H}_{2}$ : Kompetensi auditor berpengaruh positif pada kualitas audit.

Independensi juga merupakan suatu standar auditing yang sangat penting untuk dimiliki oleh auditor. Mulyadi (2014:26) mengatakan bahwa independensi berarti sikap mental yang bebas dari pengaruh, tidak dikendalikan oleh pihak lain, tidak tergantung pada orang lain. Independensi juga berarti adanya pertimbangan yang objektif dalam merumuskan dan menyatakan pendapatnya. Auditor harus dapat mempertahankan sikap mental independen karena opini yang dikeluarkan bertujuan untuk menambah kredibilitas laporan keuangan yang disajikan manajemen, sehingga jika auditor tersebut tidak independen maka kualitas audit yang dihasilkan tidak baik (Wirama 2015) dalam Ariningsih \& Mertha (2017). 
Hasil penelitian yang dilakukan oleh Deis \& Giroux (1992), Caecello \& Nagy (2004), Saputra (2012), Septriani (2012), Tepalagul \& Ling (2015), Juanta (2016), dan Ariningsih \& Mertha (2017) menyatakan bahwa independensi berpengaruh positif pada kualitas audit. Semakin tinggi independensi yang dimiliki oleh seorang auditor maka kualitas audit yang dihasilkan semakin baik.

Berdasarkan hasil penelitian di atas serta kesimpulan dari landasan teori yang ada, maka dapat ditetapkan hipotesis sebagai berikut :

$\mathrm{H}_{3}$ : Independensi auditor berpengaruh positif pada kualitas audit.

\section{METODE PENELITIAN}

Penelitian ini dilakukan pada Kantor Badan Pemeriksa Keuangan (BPK) perwakilan Provinsi Bali yang beralamat di Jalan Panjaitan Kelod No.2, Sumerta Kelod, Denpasar Timur, Kota Denpasar, Bali. Kantor Badan Pemeriksa Keuangan (BPK) perwakilan Provinsi Bali dipilih menjadi lokasi penelitian karena merupakan salah satu lembaga negara yang memiliki kewenangan berdasarkan perundang-undangan yang berlaku untuk melakukan audit investigatif terhadap keuangan dan negara/daerah. Populasi dalam penelitian ini adalah seluruh auditor di Kantor BPK Perwakilan Provinsi Bali. Populasi auditor di BPK RI perwakila Provinsi Bali sebanyak 44 orang.

Analisis regresi linier berganda dipergunakan untuk mengetahui ketergantungan satu variable terikat hanya pada satu variable bebas dengan atau tanpa moderator, serta untuk mengetahui ketergantungan satu variable terikat pada 
Putu Dendy Pratama Yoga dan Ni Luh Sari Widhiyani. Pengaruh ...

variable-variabel bebas. Teknik analisis ini digunakan untuk mengetahui pengaruh skeptisme professional, kompetensi, dan independensi terhadap kualitas audit oleh auditor pada BPK Perwakilan Provinsi Bali. Permasaan regresinya adalah

$$
\hat{Y}=\alpha+\beta_{1} X_{1}+\beta_{2} X_{2}+\beta_{3} X_{3}+\varepsilon
$$

Keterangan:

$\hat{Y} \quad:$ kualitas audit

$\alpha \quad$ : nilai konstanta

$\mathrm{X}_{1} \quad$ : skeptisme professional

$\mathrm{X}_{2}$ : kompetensi

$\mathrm{X}_{3} \quad$ : independensi

$\beta_{1} \quad$ : koefisien regresi dari skeptisme professional $\left(\mathrm{X}_{1}\right)$

$\beta_{2} \quad$ : koefisien regresi dari kompetensi $\left(\mathrm{X}_{2}\right)$

$\beta_{3} \quad$ : koefisien regresi dari independensi $\left(\mathrm{X}_{3}\right)$

$\varepsilon \quad$ : error

Berdasarkan analisis regresi diamati Goodness of Fit-nya yaitu: koefisien determinasi $\left(\mathrm{R}^{2}\right)$, uji kelayakan model (Uji F), dan uji hipotesis (Uji t).

\section{HASIL DAN PEMBAHASAN}

Pengisian kuesioner ini dilakukan oleh auditor yang terdapat pada BPK di Provinsi Bali. Profil dari 36 responden yang berpartisipasi dalam penelitian ini dapat dilihat pada Tabel 1.

Tabel 1.

Karakteristik Responden

\begin{tabular}{llll}
\hline No & Kriteria & Jumlah (orang) & Persentase (\%) \\
\hline 1 & Jabatan & &
\end{tabular}




\begin{tabular}{|c|c|c|c|}
\hline & Auditor Senior & 17 & $48 \%$ \\
\hline & Auditor Junior & 19 & $52 \%$ \\
\hline & Total & 36 & 100 \\
\hline \multirow[t]{6}{*}{2} & Umur & & \\
\hline & 20 - 30 tahun & 11 & $30 \%$ \\
\hline & $31-40$ tahun & 15 & $42 \%$ \\
\hline & $41-50$ tahun & 10 & $28 \%$ \\
\hline & $>50$ tahun & 0 & \\
\hline & Total & 36 & 100 \\
\hline \multirow[t]{6}{*}{3} & Pendidikan Terakhir & & \\
\hline & D3 & 0 & $0 \%$ \\
\hline & $\mathrm{S} 1$ & 29 & $81 \%$ \\
\hline & $\mathrm{S} 2$ & 7 & $19 \%$ \\
\hline & S3 & 0 & \\
\hline & Total & 36 & 100 \\
\hline \multirow[t]{6}{*}{4} & Lama Bekerja & & \\
\hline & $<1$ tahun & 0 & $0 \%$ \\
\hline & $1-2$ tahun & 0 & $0 \%$ \\
\hline & $2-3$ tahun & 5 & $14 \%$ \\
\hline & $>3$ tahun & 31 & $86 \%$ \\
\hline & Total & 36 & 100 \\
\hline
\end{tabular}

Sumber: Data diolah, 2018

Karakteristik responden berdasarkan jabatan untuk mengetahui kedudukan dan tangggungjawab responden di BPK. Tabel 1 menunjukkan bahwa responden yang memiliki jabatan sebagai auditor junior sebanyak 19 orang (52\%), jabatan sebagai auditor senior sebanyak 17 orang (48\%), dan tidak ada responden yang memiliki jabatan sebagai manajer, partner, dan supervisor. Hal ini menunjukkan bahwa mayoritas responden dengan jabatan sebagai auditor junior.

Karakteristik responden berdasarkan umur berfungsi untuk mengetahui umur auditor yang bekerja di KAP. Tabel 1 menunjukkan bahwa responden yang berusia 20 - 30 sebanyak 11 orang (30\%), responden yang berusia 31 - 40 sebanyak 15 orang (42), responden yang berusia 41 - 50 sebanyak 10 orang (28\%), responden yang berusia lebih dari 50 tahun sebanyak 0 orang $(0 \%)$. Hal ini menunjukkan bahwa mayoritas responden berusia 31 - 40 tahun. 
Putu Dendy Pratama Yoga dan Ni Luh Sari Widhiyani. Pengaruh ...

Karakteristik responden berdasarkan tingkat pendidikan terakhir untuk mengetahui pemahaman, dan intelektual responden. Tabel 4.3 menunjukkan bahwa responden yang memiliki tingkat pendidikan pada jenjang D3 sebanyak 0 orang (0\%), pada jenjang S1 sebanyak 29 orang (81\%), pada jenjang S2 sebanyak 7 orang (19\%), dan pada jenjang S3 sebanyak 0 orang (0\%) yang berarti pendiri KAP yang memiliki jenjang pendidikan S3 tidak ikut mengisi kuesioner. Hal ini menunjukkan bahwa mayoritas responden adalah responden dengan tingkat pendidikan pada jenjang S1.

Karakteristik responden berdasarkan lama bekerja untuk mengetahui lamanya pengalaman audit yang dimiliki auditor selama bekerja di KAP. Tabel 1 menunjukkan bahwa responden yang bekerja kurang dari 1 tahun dan bekerja selama 1 sampai 2 tahun sebanyak 0 orang (0\%), bekerja selama 2 sampai 3 tahun sebanyak 5 orang (14\%), dan bekerja selama lebih dari 3 tahun sebanyak 31 orang (86\%). Hal ini menunjukkan bahwa mayoritas responden telah bekerja selama lebih dari 3 tahun.

Uji normalitas bertujuan untuk menguji apakah distribusi data mengikuti atau mendekati distribusi normal. Pada penelitian ini, uji normalitas menggunakan uji statistikyaitu dengan uji Kolmogorov-Smirnov. Jika nilai probability asymp.sig (2-tailed) yang dihasilkan > 0,05 maka data berdistribusi normal. Hasil dengan menggunakan uji Kolmogorov-Smirnovdapat dilihat pada Tabel 2.

Tabel 2.

Hasil Uji Normalitas 


\begin{tabular}{cc}
\hline $\mathrm{N}$ & 36 \\
Asymp.Sig(2-tailed) & 0,551 \\
\hline Sumber: Data diolah, 2018 &
\end{tabular}

Berdasarkan Tabel 2 tersebut menunjukkan bahwa Asymp.Sig.(2-tailed) sebesar 0,200 > dari level of significant $(0,05)$, sehingga dapat disimpulkan bahwa variabel dalam penelitian ini berdistribusi normal.

Uji multikolinearitas bertujuan untuk menguji apakah dalam model regresi ditemukan adanya korelasi antar variabel bebas. Apabila nilai VIF kurang dari 10 atau nilai tolerance lebih besar dari 0,1 (10\%), maka dapat dikatakan bahwa tidak ada multikolinearitas.

Tabel 3 menunjukkan bahwa nilai tolerance masing-masing variabel lebih besar dari 0,1 dan nilai VIF lebih kecil dari 10, sehingga dapat dinyatakan bahwa dalam regresi tersebut tidak terjadi multikolinearitas.

Tabel 3.

Hasil Uji Multikolinieritas

\begin{tabular}{lcc}
\hline \multicolumn{1}{c}{ Variabel } & Tolerance & VIF \\
\hline Skeptisme Profesional $\left(\mathrm{X}_{1}\right)$ & 0,953 & 1,050 \\
Kompetensi $\left(\mathrm{X}_{2}\right)$ & 0,694 & 1,441 \\
Independensi $\left(\mathrm{X}_{3}\right)$ & 0,669 & 1,496 \\
\hline Sumber $:$ Data diolah, 2018 & &
\end{tabular}

Uji heteroskedastisitas bertujuan untuk menguji apakah dalam model regresi terjadi ketidaksamaan hasil dari residual satu ke pengamatan ke pengamatan yang lain. Heteroskedastisitas diuji dengan menggunakan uji Glejser yaitu dengan cara meregresikan nilai absolute residual terhadap variabel independen. Jika tingkat signifikan berada di atas 0,05 maka model regresi ini 
Putu Dendy Pratama Yoga dan Ni Luh Sari Widhiyani. Pengaruh ...

bebas dari masalah heteroskedastisitas. Hasil uji heteroskedastisitas dapat dilihat pada Tabel 4 .

Tabel 4.

Uji Heteroskedastisitas

\begin{tabular}{lccc}
\hline & Model & Sig & Keterangan \\
& & (2-tailed) & \\
\hline 1 (Constant) & & 0,514 & Bebas Heteroskedastisitas \\
& X1 & 0,479 & Bebas Heteroskedastisitas \\
& X2 & 0,391 & Bebas Heteroskedastisitas \\
\hline
\end{tabular}

Sumber: Data diolah, 2018

Berdasarkan hasil pengujian yang ditunjukkan pada Tabel 4 tingkat signifikansi semua variabel berada di atas 0,05 . Hal ini menunjukkan bahwa model regresi ini bebas dari masalah heteroskedastisitas.

Analisis ini digunakan untuk mengetahui besarnya pengaruh variabel variabel bebas (independen) yaitu Skeptisme Profesioanal, Kompetensi, dan Independensi terhadap variabel terikat (dependen) yaitu Kualitas Audit. besarnya pengaruh variabel independen yaitu Skeptisme profesional, Kompetensi, dan Independensi dengan variabel dependen yaitu Kualitas Audit secara bersama-sama dapatdihitung melalui suatu persamaan regresi berganda. Berdasarkan perhitungan diperoleh hasil regresi pada Tabel 5.

Tabel 5.

Model Summary

\begin{tabular}{|c|c|c|c|c|c|c|c|}
\hline \multirow[t]{2}{*}{ Model } & \multicolumn{2}{|c|}{$\begin{array}{c}\text { Unstandardized } \\
\text { Coefficients }\end{array}$} & \multirow{2}{*}{$\begin{array}{c}\text { Standardized } \\
\text { Coefficients }\end{array}$} & \multirow[t]{2}{*}{$T$} & \multirow[t]{2}{*}{ Sig } & \multicolumn{2}{|c|}{$\begin{array}{l}\text { Collinearity } \\
\text { Statictics }\end{array}$} \\
\hline & $B$ & Std Error & & & & Tollerance & $V I F$ \\
\hline (constant) & $-1,798$ & 6,723 & - & $-0,267$ & 0,791 & - & - \\
\hline $\mathrm{X} 1$ & 0,295 & 0,162 & 0,231 & 1,824 & 0,001 & 0,953 & 1,05 \\
\hline $\mathrm{X} 2$ & 0,687 & 0,146 & 0,697 & 4,698 & 0 & 0,694 & 1,441 \\
\hline $\mathrm{X} 3$ & 0,036 & 0,132 & 0,042 & 0,277 & 0,003 & 0,669 & 1,496 \\
\hline \multicolumn{3}{|c|}{ Adj. R Square $\left(\mathrm{R}^{2}\right)$} & \multicolumn{5}{|c|}{0,466} \\
\hline \multicolumn{3}{|c|}{ Signifikansi F } & \multicolumn{5}{|c|}{11,467} \\
\hline
\end{tabular}


Berdasarkan tabel 5 maka peramaan regresi yang terbentuk pada uji regresi ini adalah $\mathrm{Y}=-1,798+0,295 \mathrm{X} 1+0,687 \mathrm{X} 2-0,036 \mathrm{X} 3+\mathrm{e}$.

Koefisien regresi variabel X1 (Skeptisme Profesional) diperoleh sebesar 0,295 dengan arah koefisien positif. Hal ini menunjukkan bahwa semakin tinggi sikap skeptis yang di miliki auditor dapat meningkatkan kualitas audit dalam pemeriksaan laporan keuangan.

Koefisien regresi variabel X2 (Kompetensi) diperoleh sebesar 0,687 dengan arah koefisien positif. Hal ini menunjukkan bahwa semakin berkompeten seorang auditor dapat meningkatkan kualitas audit dalam pemeriksaan laporan keuangan.

Koefisien regresi variabel X3 (Independensi) diperoleh sebesar 0,036 dengan arah koefisien positif. Hal ini menunjukkan bahwa independensi dapat meningkatkan kualitas audit dalam pemeriksaan laporan keuangan.

Uji F (F-test) dimaksudkan untuk mngertahui pengaruh variabel-variabel independen yaitu skeptisme profesional, kompetensi dan independensi secara simultan (bersama-sama). Uji F pada dasarnya menunjukkan apakah semua variabel bebas yang dimasukkan dalam model mempunyai pengaruh secara bersama-sama pada variabel dependen. Berdasarkan hasil perhitungan uji $\mathrm{F}$ pada Tabel 4.8 menunjukkan bahwa nilai $F_{\text {hitung }}$ sebesar 11,467 dengan nilai signifikansi $\mathrm{F}$ atau $p$-value sebesar 0,000 yang lebih kecil dari nilai $\alpha=0,05$. 
Putu Dendy Pratama Yoga dan Ni Luh Sari Widhiyani. Pengaruh ...

Artinya variabel skeptisme profesional, kompetensi dan independensi secara bersama-sama (simultan) berpengaruh pada kualitas audit,

Berdasarkan hasil perhitungan estimasi regresi pada Tabel 5 diperoleh nilai Koefisien Determinasi $\left(\mathrm{R}^{2}\right)$ adalah 0,466 artinya $46,6 \%$ variasi dari semua variabel bebas seperti Skeptisme Profesional, Kompetensi, dan Independensi dapat menerangkan variabel tak bebas yaitu kualitas audit, sedangkan sisanya sebesar 53,4\% diterangkan oleh variabel lain yang tidak diajukan dalam penelitian ini.

Tabel 5.

Pengujian Hipotesis

\begin{tabular}{|c|c|c|c|c|c|c|c|}
\hline \multirow[t]{2}{*}{ Model } & \multicolumn{2}{|c|}{$\begin{array}{c}\text { Unstandardized } \\
\text { Coefficients }\end{array}$} & \multirow{2}{*}{$\begin{array}{c}\text { Standardized } \\
\text { Coefficients } \\
\text { Beta }\end{array}$} & \multirow[t]{2}{*}{$T$} & \multirow[t]{2}{*}{ Sig } & \multicolumn{2}{|c|}{ Collinearity Statictics } \\
\hline & $B$ & Std Error & & & & Tollerance & $V I F$ \\
\hline (constant) & $-1,798$ & 6,723 & & $-0,267$ & 0,791 & & \\
\hline $\mathrm{X} 1$ & 0,295 & 0,162 & 0,231 & 1,824 & 0,001 & 0,953 & 1,05 \\
\hline $\mathrm{X} 2$ & 0,687 & 0,146 & 0,697 & 4,698 & 0 & 0,694 & 1,441 \\
\hline $\mathrm{X} 3$ & 0,036 & 0,132 & 0,042 & 0,277 & 0,003 & 0,669 & 1,496 \\
\hline
\end{tabular}

Dari hasil perhitungan didapat nilai $\mathrm{t}$ sebesar 1,824 dengan tingkat signifikansi sebesar 0,001, apablia dilihat dari nilai signifikasinya yang kurang dari 0,05, ini berarti variabel pengalaman berpengaruh signifikan terhadap kualitas audit, sedangkan berdasarkan persamaan regresi terlihat bahwa koefisien variabel pengalaman adalah positif, hal ini berarti meningkatnya persepsi responden terhadap skeptisme professional dapat berakibat pada peningkatankualitas audit. Dengan demikian dapat disimpulkan H1 diterima. Artinya sikap skeptisme profesional yang lebih besar secara signifikan dapat meningkatkan kualitas audit dalam pemeriksanaan laporan keuangan. 
Dari hasil perhitungan didapat nilai $\mathrm{t}$ sebesar 4,698 dengan tingkat signifikansi sebesaar 0,000. Apabila dilihat dari nilai signifikasinya yang kurang dari 0,05 , ini berarti variabel pengetahuan berpengaruh secara signifikan terhadap kualitas audit. sedangkan berdasarkan persamaan regresi terlihat bahwa koefisien variabel kompetensi adalah positif, hal ini berarti meningkatnya persepsi responden terhadap kompetensi dapat berakibat pada peningkatan kualitas audit. Dengan demikian dapat disimpulkan $\mathrm{H} 2$ diterima. Artinya kompetensi yang lebih besar secara signifikan dapat meningkatkan kualitas audit dalam pemeriksanaan laporan keuangan.

Dari hasil perhitungan didapat nilai $\mathrm{t}$ sebesar 0,277 dengan tingkat signifikansi sebesar 0,003. Apabila dilihat dari nilai signifikansinya yang kurang dari 0,05 , ini berarti variable independensiberpengaruh secara signifikan terhadap kualitas audit, sedangkan berdasar persamaan regresi terlihat bahwa koefisien variabel lama independensi adalah positif, hal ini berarti meningkatnya persepsi responden terhadap independensi dapat berakibat pada peningkatan kualitas audit. Dengan demikian dapat disimpulkan H3 diterima. Artinya keberadaan independensilebih besar secara signifikan dapat meningkatkan kualitas audit dalam pemeriksanaan laporan keuangan.

Berdasarkan hasil analisis data diketahui bahwa variabel skeptisme professional, kompetensi, dan independensi secara individu dan bersama-sama signifikan mempengaruhi Kualitas Audit. Variabel skeptisme professional, kompetensi dan independensi berpengaruh positif pada Kualitas Audit. 
Putu Dendy Pratama Yoga dan Ni Luh Sari Widhiyani. Pengaruh ...

Hipotesis pertama $\left(\mathrm{H}_{1}\right)$ yang menyatakan bahwa skeptisme profesional berpengaruh positif pada kinerja auditor. Setelah dilakukan pengujian, hasil penelitian menunjukkan bahwa nilai koefisien regresi sebesar 0,295. Hal ini menunjukkan bahwa variabel skeptisme profesional berpengaruh positif pada kinerja auditor, maka hipotesis $\left(\mathrm{H}_{1}\right)$ diterima.

Hal ini menunjukkan bahwa, semakin meningkat skeptisme profesional yang dimiliki auditor di BPK maka kinerja auditor akan meningkat dan sebaliknya jika skeptisme profesional yang dimiliki auditor rendah, maka kinerja auditor akan menurun. Hubungan antara skeptisme profesional auditor dengan kinerja adalah apabila seorang auditor memiliki sikap skeptisme profesional yang tinggi maka kinerjanya akan meningkat. Kondisi tersebut menyebabkan auditor akan dipercaya dan diandalkan dalam menyelesaikan pekerjaannya, sehingga dapat mendatangkan hasil yang diharapkan.

Hasil penelitian ini didukung oleh penelitian yang dilakukan oleh Januarti dan Faial (2010) menunjukkan hasil bahwa skeptisme profesional auditor mempunyai pengaruh yang positif terhadap kualitas hasil audit. Prima \& Rohman (2012) menunjukkan hasil bahwa skeptisme profesional auditor berpengaruh positif terhadap kualitas audit, sehingga semakin skeptis seorang auditor semakin baik kualitas audit yang dilakukannya. Penelitian yang dilakukan oleh Sari \& Ramantha (2015) menunjukkan hasil bahwa skeptisme profesional auditor berpengaruh positif dan signifikan terhadap kualitas audit. 
Hipotesis kedua $\left(\mathrm{H}_{2}\right)$ yang menyatakan bahwa kompetensi berpengaruh positif pada kinerja auditor. Setelah dilakukan pengujian, hasil penelitian menunjukkan bahwa nilai koefisien regresi sebesar 0,687 . Hal ini menunjukkan bahwa variabel kompetensi berpengaruh positif pada kinerja auditor, maka hipotesis $\left(\mathrm{H}_{2}\right)$ diterima.

Hal ini menunjukkan bahwa, semakin berkompeten auditor di BPK maka kinerja auditor menjadi semakin meningkat, dan sebaliknya. Kompetensi auditor memiliki masalah penting yang berhubungan atau memiliki kaitan dengan tingkat ketelitian auditor. Hubungan antara kompetensi auditor dengan kinerja adalah apabila seorang auditor memiliki kompetensi yang tinggi maka kinerjanya akan meningkat. Kondisi tersebut menyebabkan auditor akan dipercaya dan diandalkan dalam menyelesaikan pekerjaannya, sehingga dapat mendatangkan hasil yang diharapkan.

Hasil penelitian ini didukung oleh penelitian Penelitian Christiawan (2002) dan Alim et al. (2007) dalam Sukriah et al. (2009) menyatakan bahwa semakin tinggi kompetensi auditor akan semakin baik kualitas hasil pemeriksaannya. Kemudian Ermayanti (2009) mengemukakan setiap auditor harus melaksanakan jasa profesionalnya dengan hati-hati, kompetensi dan ketekunan, serta mempunyai kewajiban untuk mempertahankan pengetahuan dan keterampilan professional. Penelitian Efendy (2010) menyatakan bahwa kompetensi berpengaruh positif terhadap kualitas audit. Penelitian yang dilakukan Anugerah \& Akbar (2014) menunjukkan bahwa kompetensi berpengaruh positif terhadap kualitas audit. 
Putu Dendy Pratama Yoga dan Ni Luh Sari Widhiyani. Pengaruh ...

Hipotesis ketiga $\left(\mathrm{H}_{3}\right)$ yang menyatakan bahwa independensi berpengaruh positif pada kinerja auditor. Setelah dilakukan pengujian, hasil penelitian menunjukkan bahwa nilai koefisien regresi sebesar 0,036 . Hal ini menunjukkan bahwa variabel independensi berpengaruh positif pada kinerja auditor, maka hipotesis $\left(\mathrm{H}_{2}\right)$ diterima.

Hal ini menunjukan bahwa semakin meningkat independensi auditor di BPK, maka kinerja auditor semakin baik dalam menyelesaikan tugas-tugasnya. Independensi akan muncul ketika seorang auditor yang melaksanakan tugasnya dihadapkan dengan permintaan klien yang tidak sesuai dengan hasil yang dikerjakan. Hubungan antara Independensi auditor dengan kinerja adalah apabila seorang auditor memiliki independensi yang tinggi maka auditor tersebut tidak akan mudah terpengaruh dan dikendalikan oleh pihak lain. Kondisi tersebut menyebabkan auditor akan dipercaya dan diandalkan dalam menyelesaikan pekerjaannya, sehingga dapat mendatangkan hasil yang diharapkan.

Hasil penelitian yang dilakukan oleh Deis \& Giroux (1992), Caecello \& Nagy (2004), Saputra (2012), Septriani (2012), Tepalagul \& Ling (2015), Juanta (2016), dan Ariningsih \& Mertha (2017) menyatakan bahwa independensi berpengaruh positif pada kualitas audit. Semakin tinggi independensi yang dimiliki oleh seorang auditor maka kualitas audit yang dihasilkan semakin baik.

Hasil penelitian ini diharapkan dapat memberikan tambahan informasi mengenai pengaruh skpetisme profesional, kompetensi, dan independensi pada kualitas audit. Terdapat bukti empiris bagi peneliti dalam pengaruh skeptisme 
profesional, kompetensi, dan independensi yang berhubungan dengan kualitas audit. Hal ini menunjukkan semakin tinggi skeptisme profesional, kompetensi, dan independensi seorang auditor maka semakin meningkat kualitas audit. Hal ini didukung dengan adanya teori kegenan yang menyebutkan bahwa adanya auditor independen diharapkan dapat mengurangi konflik kepentingan antara principal dan agent sekaligus dapat mengevaluasi kinerja pihak manajemen serta diharapkan dapat dijadikan dasar pengambilan keputusan bagi pihak-pihak yang berkepentingan.

Hasil penelitian ini dapat menjadi pertimbangan bagi klien dalam memilih auditor independen untuk mengatasi konflik kepentingan serta dalam mengevaluasi kinerja manajemen. Serta bagi auditor agar tetap mempertahankan sikap skeptisme profesional dan independensi serta meningkatkan kompetensi untuk dapat menghasilkan dan meningkatkan kualitas audit.

\section{SIMPULAN}

Sikap skeptisme dalam melaksanakan audit berpengaruh positif pada kualitas audit yang berarti semakin tinggi sikap skeptis seorang auditor maka akan semakin baik kualitas audit yang dilakukannya. Kompetensi seorang auditor berpengaruh positif pada kualitas audit yang berarti semakin baik kompetensi auditor maka akan semakin baik kualitas audit yang dihasilkan. Independensi berpengaruh positif pada kualitas audit yang berarti semakin tinggi independesi auditor maka kualitas audit yag dilakukan auditor cenderung semakin tinggi. 
Putu Dendy Pratama Yoga dan Ni Luh Sari Widhiyani. Pengaruh ...

Melihat Skeptisme professional, kompetensi, dan independensi terbutkti mampu memberikan pengaruh pada kualitas auditmaka saran yang dapat diberikan peneliti untuk BPK, auditor diharapkan dapat meningkatkan kompetensinya dan mempertahankan sikap objektif serta independensi sehingga kedepannya dapat meningkatkan kualitas audit.

Diharapkan penelitian ini dapat dijadikan pertimbangan oleh penelitiannya selanjutnya. Selain itu mengandung beberapa kelemahan terkait dengan persepsi kuesioner yang mungkin saja tidak sesuai dengan realitas yang dialami auditor. Bagi peneliti selanjutnya disarankan untuk dapat memperoleh sampel yang lebih banyak agar hasil yang diperoleh lebih representatif serta meningkatkan kualitas data yang akan dianalisis melalui metode wawancara atau observasi langsung kepada responden agar dapat memperkuat hasil penelitian.

\section{REFERENSI}

Alim, M. N., Hapsari, T., \& Purwanti, L. (2007). Pengaruh Kompetensi dan Independensi terhadap Kualitas Audit dengan Etika Auditor Sebagai Variabel Moderasi. Simposium Nasional Akuntansi X.

Andarwanto, A. (2015). Pengaruh Kompetensi, Independensi, Akuntanbilitas dan Profesionalisme Auditor terhadap Kualitas Audit (Studi Empiris pada KAP di Surakarta dan Yogyakarta). Universitas Muhammadiyah Surakarta.

Anugerah, R., \& Akbar, H. sony. (2014). Pengaruh Kompetensi, Kompleksitas Tugas dan Skeptisme Profesional terhadap Kualitas Audit. Jurnal Akuntansi, 2(2), 139-148. https://doi.org/10.1016/j.jaap.2015.03.007

Ardini, L. (2010). Pengaruh Kompetensi, Independensi, Akuntabilitas dan Motivasi terhadap Kualitas Audit. Majalah Ekonomi, (3), 329-349. https://doi.org/10.1523/JNEUROSCI.6376-10.2011 
Ariningsih, P. S., \& Mertha, I. (2017). Pengaruh Independensi, Tekanan Anggaran Waktu, Risiko Audit, dan Gender pada Kualitas Audit. E-Jurnal Akuntansi Universitas Udayana.

Ayu, D. (2013). Pengaruh Keahlian, Independensi, dan Etika Terhadap Kualitas Audit. Universitas Hasanuddin.

Badjuri, A. (2011). Faktor-Faktor Yang Berpengaruh Terhadap Kualitas Audit Auditor Independen Pada Kantor Akuntan Publik (KAP) Di Jawa Tengah. Dinamika Keuangan Dan Perbankan, 3(2), 114-121.

BPK-RI. (2007). Peraturan Badan Pemeriksa Keuangan RI No 1, Tahun 2007 tentang SPKN. Jakarta: Badan Pemeriksa Keuangan RI.

CAQ. (2010). Deterring and Detecting Financial Auditing Fraud-A Platform for Action.

Castellani, J. (2008). Kompetensi dan Independensi Auditor Pengaruhnya pada Kualitas Audit. Trikonomika, 7(2), 114-121.

Christiawan, Y. J. (2002). Kompetensi dan dndependensi akuntan publik : refleksi hasil penelitian empiris. Jurnal Akuntansi Dan Keuangan, 4(2), 79-92. https://doi.org/10.9744/jak.4.2.pp. 79-92

DeAngelo, L. E. (1981). Auditor Size and Audit Quality. Journal of Accounting and Economics 3, 3, 183-199. https://doi.org/10.1016/0165-4101(81)900021

Deis, D. R., \& Giroux, G. . (1992). Determinants of Audit Quality in the Public Sector. The Accounting Review, 67(3), 462-479.

Efendy, M. T. (2010). Pengaruh Kompetensi, Independensi, dan Motivasi Terhadap Kualitas Audit Aparat Inspektorat Dalam Pengawasan Keuangan Daerah. Universitas Diponegoro Semarang.

Elfarini, E. C. (2007). Pengaruh Kompetensi Dan Independensi Auditor Terhadap Kualitas Audit (Studi Empiris Pada Kantor Akuntan Publik Di Jawa Tengah). Universitas Negeri Semarang.

Indah, S. N. (2010). Pengaruh Kompetensi dan Independensi Auditor Terhadap Kualitas Audit. Universitas Diponegoro.

Islahuzzaman. (2012). Istilah-istilah Akuntansi \& Auditing. (1st ed.). Jakarta: 
Bumi Aksara.

Jones, G., \& Bowrey, G. (2013). Local council governance and audit committees the missing link. Journal of New Business Ideas AndTrends, 11(2).

Marganingsih. (2016). Pengaruh Indepndensi, Kompetensi, Akuntanbilitasn Pengalaman dan Motivasi Terhadap Kualitas Audit Pada Aparat Inspektorat dalam Pengawasan Keuangan Daerah. Universitas Muhammadiyah Surakarta.

Mulyadi. (2014). Auditing (6th ed.). Jakarta: Salemba Empat.

Oklivia, \& Marlinah, A. (2014). Pengaruh Kompetensi, Independensi, Obyektivitas, Integritas dan Akuntabilitas Terhadap Kualitas Audit di Pemerintah Daerah (Studi Empiris Pada 5 Kantor Inspektorat Provinsi Bali). Jurnal Bisnis Dan Akuntansi, 16(2), 143-157.

Prima, Q. P., \& Rohman, A. (2012). Analisis Faktor-Faktor Yang Mempengaruhi Kualitas Audit Aparat Inspektorat Kota/Kabupaten Di Jawa Tengah. Diponegoron Journal Of Accounting, 1(2).

Rapina, Saragi, L. M., \& Carolina, V. (2010). Pengaruh Independensi Eksternal Auditor Terhadap Kualitas Pelaksanaan Audit (Studi Kasus Pada Beberapa Kantor Akuntan Publik Di Bandung), 1(2).

Sari, \& Ramantha. (2015). Pengaruh Sikap Skeptisme, Pengalaman Audit, Kompetensi, dan Independensi Auditor pada Kualitas Audit. Universitas Udayana.

Septriani, Y. (2012). Pengaruh Independensi dan Kompetensi Auditor Terhadap Kualitas Audit. Jurnal Akuntansi \& Manajemen. Jurnal Akuntansi \& Manajemen, 7(2). 